\title{
ВИЗНАЧЕННЯ ГОЛОВНИХ ФЕНОМЕНІВ САМОСВІДОМОСТІ ОСОБИСТОСТІ
}

\section{Білецъкий Олексій Миколайович \\ Кандидат психологічних наук, керуючий иеентром розвитку особистості «Школа Життя», м. Київ (Украӥна)}

\begin{abstract}
Анотація. Стаття присвячена вивченню останніх досліджень основних феноменів самосвідомості, які розкривають механізми їх реалізащії та ієрархію впливу на розвиток особистості. Визначено головну роль самопізнання в процесі розвитку самосвідомості особистості. По результатам дослідження встановлена різниця в поняттях таких феноменів самосвідомості як самовідношення та самооиінка. Ретельно розглянуті особливості механізму реалізації самооцінки. Окремо виділені феномени самоактуалізації та самореалізації, які мають визначальний вплив на розгортання Я-Концепиії особистості, як продукту ї̈ самосвідомості. В роботі вказано на подальшу необхідність визначення в конкретних наукових поняттях чітких закономірностей взаємодії вказаних феноменів самосвідомості та їх конкретну роль в процесі розвитку особистості.
\end{abstract}

Ключові слова: самосвідомість, феномени самосвідомості, самопізнання, самовідношення, самооцінка, саморегуляція, самоконтроль, самовиховання, самоактуалізація, самореалізація.

\section{Постановка проблеми у загальному} вигляді. Головну роль в конструюванні нового стилю життя і трансформації внутрішнього світу особистості сучасна психологія справедливо відводить самосвідомості особистості.

Але й до теперішнього часу відсутній єдиний підхід в чіткому визначенні феноменів самосвідомості не дивлячись на те, що вони активно вивчаються як вітчизняними (Б. Г. Ананьєв, О. О. Бодальов, Л. І. Божович, Л. С. Виготський, І. С. Кон, С. Л. Рубінштейн,
В. В. Столін, I. I. Чеснокова та ін.), так і зарубіжними дослідниками (Р. Бернс, У. Джемс, Е. Еріксон, А. Маслоу, Г. Олпорт, К. Роджерс, В. Франкл, 3. Фрейд, К. Хорні та ін.). Аналіз робіт, присвячених самосвідомості, дозволяє говорити про велику різноманітність використовуваних для опису його механізмів психологічних категорій. Можна назвати такі поняття як самопізнання, самооцінка, эмоційноціннісне відношення до себе, самовідношення, самоконтроль, саморегуляція, самоаналіз, са- 
мовиховання, самовдосконалення, самоспостереження та ін.

Відсутність чіткої термінології привела до того, що феномени самосвідомості більшістю авторів не розрізняються, вони найчастіше підміняють один феномен іншим або об'єднують значення декількох феноменів в один. В той же час, змістовний аналіз цих понять дозволяє досконаліше в них розібратися.

Аналіз останніх досліджень і публікацій. Дослідники самосвідомості останнього десятиліття (Ю. А. Алексеева, М. О. Антонець, І. Д. Бех, О. М. Білецький, І. С. Булах, О. М. Васильченко, П. В. Макаренко, Л. Л. Макарова, Я. В. Мацегора, Г.І. Меднікова, О. Я. Надибська, Г. М. Свіденська, Л. П. Чепіга, В. О. Швидкий та ін.) у своїх наукових працях розглядають різноманітні феномени самосвідомості, але й досі єдиної думки 3 приводу сфери реалізації останніх немає, особливо це стосується самоактуалізації та самореалізації.

Мета даної статті - теоретичний аналіз, узагальнення та систематизація досліджень основних феноменів самосвідомості, які розкривають механізми їх реалізації та ієрархію впливу на розвиток особистості.

Виклад основного матеріалу дослідження. Головним феноменом самосвідомості поправу вважається процес самопізнання. В. Столін вважає що при самопізнанні людина користується цілою системою внутрішніх засобів: уявлень, образів, понять, серед яких ва- жливу роль займає уявлення людини про саму себе, про свої особистісні риси, здібності, мотиви [14].

О. Спіркін відзначає, що життя у колективі поступово привчило людей обмірковувати свої думки та вчинки перед тим, як діяти й говорити, ураховувати можливі наслідки висловлених думок і зроблених вчинків [13]. Тому звернення до внутрішнього світу та внутрішнього життя людини є ключовим моментом в розумінні самої людини [2].

Онтогенетичний розвиток самопізнання як і інших сфер самосвідомості, - це процес, що розгортається в часі. Тому в генезисі самопізнання сучасна психологічна наука виокремлює два основних рівні $[1 ; 5 ; 11 ; 19]$.

На першому рівні співвідношення знань про себе проходить в межах співвідношення «Я та іншої людини». Спочатку якась якість сприймається в іншій людині, а потім вона переноситься на себе [19]. Основними способами пізнання себе на першому рівні самопізнання є самосприймання та прості форми самоаналізу, що не зникають і на подальших стадіях розвитку самосвідомості, для яких вони є вихідним моментом, чуттєвою основою [19].

Для другого рівня самопізнання специфічним $є$ те, що співвіднесення знань про себе здійснюється не в рамках «Я та інша людина», а в межах «Я та Я» і передбачає оперування деякою мірою сформованими знаннями про себе. Провідним способом вивчення власного 
внутрішнього світу стають складні форми самоаналізу, зокрема аналіз мотивів власної поведінки. Виділені мотиви оцінюються людиною $з$ точки зору розуміння вимог суспільства до неї та власних вимог до себе. Внаслідок співвіднесення форм поведінки з певною мотивацією; їх аналізу й оцінки відбувається усвідомлення себе як суб'єкта, якому належать виділені та проаналізовані стани і властивості. Власне «Я» починає усвідомлюватися як цілісне утворення, як єдність зовнішнього та внутрішнього буття [19].

В сучасній психологічній науці неабияку увагу приділяється такому феномену самосвідомості як самовідношення. Згідно В. Століну, самовідношення є відносно постійною характеристикою особистості. Глобальне самовідношення може зберігатися при одночасному зниженні позитивного самовідношення у рамках одних поглядів і компенсаторному зростанні у рамках інших [14].

В. Столін також підкреслює, що підтримка самовідношення $є$ основним мотивом структуризації Я-Концепції - як продукту самосвідомості [14]. Уявлення та установки особистості, як правило, узгоджуються одне з одним. Єдність «Я» означає узгодженість трьох компонентів: деякого аспекту «Я», інтерпретації особистістю своєї поведінки в цьому аспекті, i іï уявлень про те, як сприймають іiї інші люди. Щоб забезпечити таку узгодженість, особистість може використовувати ряд прийомів: спотворювати думки інших про себе, на- ближаючи їх до власної самооцінки; орієнтуватися на людей, відношення яких допомагає підтримувати звичний «образ Я»; оцінювати власні якості вибірково, залежно від того, наскільки вони важливі для загальної узгодженості «образу Я». Ці, переважно неусвідомлювані способи, дозволяють індивідові підтримувати певний рівень самоповаги [6].

\section{С. Пантілєєв припускає, що самовідно-} шення кожного суб'єкта має певну специфіку. Ця специфіка може виражатися як в емоційному тоні, так і в семантичному змісті відповідного відношення до себе. Так, для одних індивідів глобальне самовідношення може здійснюватися у формі самоповаги, а для інших - у формі симпатії до себе. Інакше кажучи, самовідношення не будується як сума емоційних проявів, а швидше втілюється в ту або іншу форму із специфічним семантичним забарвленням і певним емоційним тоном. Психологічна система самовідношення побудована за принципом динамічної ієрархії, який полягає в тому, що та або інша особлива модальність емоційного відношення може виступати ядерною структурою системи, займаючи провідне місце в ієрархії інших аспектів самовідношення і визначаючи зміст і вираженість узагальненого стійкого самовідношення [10].

\section{Теоретичні основи розуміння самовід-} ношення як компонента самосвідомості були закладені I. Часниковою, яка ввела в науковий обіг поняття «емоційно-ціннісне самовідношення». Вона визначила емоційно-ціннісне 
самовідношення як специфічний вид емоційного переживання, в якому відбивається власне відношення особистості до того, що вона дізнається, розуміє, та відкриває відносно самої себе [19].

Процес розвитку емоційно-ціннісного ставлення до себе відбувається в напрямку, з одного боку, узагальнення більш або менш однорідних, близьких за своєю модальністю і змістом переживань у складні почуття, а 3 іншого - диференціації на новому, вищому рівні почуттів з різним смисловим значенням. Різноманітні почуття, емоційні стани, пережиті в різний час, у різних життєвих ситуаціях у зв'язку з роздумами про себе, розумінням себе тощо, становлять емоційний фонд самосвідомості, який, включаючись на будь-якому рівні у процеси самопізнання та саморегулювання, значною мірою спрямовує їх, надає їм індивідуального, особистісного характеру і сам постійно уточнюється [15].

Слід зазначити, що результати інтегративної роботи в сфері самопізнання, з одного боку, й у сфері емоційно-ціннісного ставлення до себе - 3 іншого, поєднуються в особливий феномен самосвідомості особистості - іiї самооцінку [19].

У. Джемс вважав, що оцінка власних досягнень залежить від рівня домагань особистості, що знайшло своє відображення у відомій формулі: «Самоповага = Успіх / Домагання». Чим вище рівень домагань, тим важче їх задовольнити. Невдачі, як правило, знижують домагання, а успіх підвищує їx [4].
Х. Хекхаузен підкреслює, що у осіб, упевнених в успіху, «вимогливий» індекс зазвичай помірно вище за їх реальні досягнення. У людей, стурбованих можливістю невдачі, домагання частіше набувають екстремальних значень, стаючи або заниженими, або завищеними. Високий рівень домагань не є ознакою благополуччя самооцінки, а разом 3 низьким рівнем виступає сигналом невпевненості людини у своїх силах [17].

В. Кобильченко та М. Савчин вважають, що самооцінка складається 3 когнітивного та афективного компонентів. Самооцінка завжди має відтінок суб'єктивності й відбиває особливості засвоєного особистісного досвіду, ступінь глибини його усвідомлення та узагальнення. Здебільшого вона пов'язана із психічними особливостями особистості. Вони вважають, що залежно від властивостей та рис особистості самооцінка може бути стійкою, завищеною чи, навпаки, заниженою; вона пов'язана з інтелектом особистості, іï емоційністю $[12 ; 16]$.

Самооцінка - важливий орган духовного життя людини, вона регулює поведінку і діяльність людини. Самооцінка - своєрідна призма, або окуляри, які завжди переломлюють реальність. Так, упевнена в собі людина приписує свої досягнення власним заслугам; невпевнена вважає успіх випадковістю, а невдачу - закономірністю. Г. Цукерман пропонує розглядати два шари самооцінки - загальну та конкретну самооцінку [18, с.10].

Ю. Трофімов вважає, що зміст самооці- 
нки має багато аспектів, які охоплюють світ моральних цінностей особистості, її стосунків та можливостей. На його думку, єдина цілісна, глобальна, самооцінка особистості також формується на основі самооцінки окремих сторін iii психічного світу - часткових самооцінок. Кожний з компонентів самооцінки відображає ступінь знання особистістю відповідних іiї якостей і ставлення до них, має свою лінію розвитку, через що весь процес утворення загальної самооцінки має суперечливий і нерівномірний характер [15].

Як зазначив I. Кон, самооцінка, впливаючи на спрямування думок, почуттів, поведінки та діяльності, соціальна за своєю природою. Але вона, будучи суб'єктивною, не може служити достатньою підставою для самокерованої поведінки. Вона повинна порівнюватись 3 об'єктивними обставинами, 3 оцінками інших людей, колективу, суспільства [6].

Так, С. Куперсміт називає самооцінкою ставлення індивіда до себе, яке складається поступово і набуває звичного характеру. Воно проявляється як схвалення або несхвалення, ступінь якого визначає переконання індивіда в своїй самоцінності, значущості [21]. Самооцінка - це особистісне судження про власні цінності, які виражаються в установках, властивих індивіду. М. Розенберг визначає самооцінку як позитивну або негативну установку, спрямовану на специфічний об'єкт, який має назву «Я» [23].

Самооцінка дозволяє правильно визна- чити свій духовний та фізичний стан, свої стосунки із зовнішнім світом, іншими людьми. Самооцінка визначається співвідношенням своїх власних думок i вчинків із загальноприйнятими в даному суспільстві принципами та переконаннями. Різниця між цими явищами і складає той сигнал, який усвідомлюється як ступінь відхилення від вимог суспільства. Самооцінка $є$ обов'язковою умовою реалізації двох важливих етапів самокерованої поведінки: самоконтролю та самовдосконалення [19].

Ю. Трофімов зазначає, що у процесі формування єдиної самооцінки особистості провідна роль належить іiі раціональному компоненту. Саме на основі самоаналізу відбувається немовби виявлення недостатньо чітких компонентів самооцінки та їх переведення зі сфери неусвідомлюваного в сферу свідомого. На кожному конкретному етапі розвитку особистості самооцінка, з одного боку відображає рівень розвитку самопізнання та емоційноціннісного ставлення до себе, з іншого - $€$ важливою внутрішньою умовою їхнього розвитку, самооцінка завжди існує в структурі регуляції поведінки, вона надає специфічної спрямованості всьому процесові саморегулювання. Результат цього процесу прямо співвідноситься $з$ адекватністю стійкістю й глибиною самооцінки. Тільки високий рівень розвитку цих властивостей та їх інтеграція забезпечують здійснення саморегулювання на адекватному рівні [15].

У вітчизняній психології доведено, що 
процес розвитку особистості проявляється у збільшенні ролі внутрішніх чинників і вдосконаленні такого феномену самосвідомості, як саморегуляція. Високий рівень розвитку саморегуляції, який об'єктивно виражається в тонкості, диференційованості та адекватності усіх усвідомлених інтелектуальних, емоційних, поведінкових реакцій, вчинків, вербальних проявів і так далі, дає основу припускати і наявність досить зрілого стану розвитку самосвідомості в цілому. Найбільш складні форми саморегуляції виникають і як завершальний етап особистості, яка самоусвідомлює сама себе $[3 ; 11 ; 19]$.

Спираючись на раніше проведені нами дослідження процесу самосвідомості особистості, феномен саморегуляції необхідно розглядати грунтуючись на дворівневу будову ЯКонцепції, де перший рівень визначається в рамках природженого потенціалу людини (К. Роджерс, Г. Олпорт, В. Франкл, К. Юнг, А. Маслоу), а другий рівень Я-Концепції - як той, що формується у людини в процесі соціалізації і стає стійким у підлітковому віці (I. I. Чеснокова). Така психологічна модель ЯКонцепції, як продукту самосвідомості, дозволяє визначити саморегуляцію, як циклічний процес постійної актуалізації та реалізації особистістю іiі природженого потенціалу. Де самоактуалізація - це процес розвертання властивостей і характеристик людини, які містяться на першому рівні Я-Концепції, в другий рівень Я-Концепції. А самореалізація, це про- цес особистого розвитку і трансляції особистістю свого вмісту іншим людям і культурі через «Я-Концепцію другого рівня [1]. Таке розуміння самоактуалізації та самореалізації обумовлює входження цих понять в коло проблематики самосвідомості особистості [8].

Також, велику роль феномену саморегулювання в структурі самосвідомості приділяє I. Чеснокова. Вона виділяє дві форми саморегулювання: по-перше, це таке саморегулювання, яке має чіткі часові межі свого існування та обумовлене конкретним поведінковим актом, який закінчується більш менш чітким усвідомленням власної оцінки досягнутого. Інша форма саморегулювання, розтягнута в часі і пов'язана з плануванням особистістю цілеспрямованих змін в самій собі. Вона лежить в основі самовиховання особистості. Саморегулювання поведінки існує функціонально як дворівневий процес, Перший рівень саморегулювання складає управління особистістю безпосереднім протіканням поведінкового акту на усіх етапах його розгортання, другий рівень - складає дію самоконтролю, тобто безперервне дослідження особистістю усіх ланок регуляції поведінки, їх зв'язку, внутрішньої логіки [19, с.135].

Самоконтроль, в свою чергу, зорієнтований на зовнішні речі та свідомість, основним об'єктом якої є людське «Я», тобто самопізнання [13]. У першому значенні самосвідомість як самоконтроль зорієнтована на реалізацію заклику: пізнай світ, а в другому - на 
реалізацію заклику: пізнай самого себе. Самоконтроль - це керована поведінка, тобто здатність індивіда впливати не лише на формування мотивації дії, а й на її виконання [9, с. 391].

Самоконтроль - постійний звіт особистості перед самою собою про співвіднесеність мети, мотиву дії і протіканням самої дії; це постійна внутрішня готовність перевести дію в інший напрямок, змінити іiі, додати деякі додаткові моменти, корективи; це як би спілкування усередині самої особистості - між особистістю у дії і особистістю, яка планує дію; відповідно до певної мети поведінки [19].

Т. Шибутані вважав, що самоконтроль - це складна форма поведінки, яка пов'язана зі здатністю подивитися на себе збоку, сформувати 3 точки зору інших «Я-образ» i пристосуватись до випереджених дій [20].

Саме у здатності людини до самоконтролю виявляється рівень їі соціального розвитку. Здійснення самоконтролю покликано тримати людину в рамках суспільних вимог і пов'язане 3 постійним подоланням протиріч між особистими бажаннями, соціальними обов'язками, моральними нормами, які загальноприйняті в суспільстві [24].

Г. Саготський та П. Леккі вважають що важливими засобами, за допомогою яких діти навчаються керувати власною поведінкою та контролювати іiі, є самоперевірка та самоінструктування [22; 24].

Найціннішою психологічною якістю особистості, для творчого підходу до самого себе являється самокритика. Згідно I. Часниковою, самокритика являється важливим критерієм для переходу від першої системи саморегулювання «Я та інші» до другої системи саморегулювання «Я і Я», яка спрямована на свідому роботу особистості над собою [19].

За думкою П. Леккі, індивід є цілісною системою, перед якою стоїть завдання досягнення гармонії з навколишнім середовищем. Розв'язуючи це завдання, індивід може або відмовитися дивитися на речі такими, які вони $\epsilon$, та вірити людям, або намагатися змінити якимось чином себе або оточуючих [22, с. 140].

Вищою формою саморегуляції особистістю своєї поведінки й діяльності , $є$ самовиховання, яке не може бути відокремлене від відповідного високого рівня зрілості процесів самопізнання та емоційно-ціннісного відношення до себе, від адекватної та відносно стійкої самооцінки [19].

О. Крилов, під самовихованням розуміє самозмінювання особистості відповідно до певної програми, яка утримує цілі і завдання, а також відносно стабілізовані критерії цих цілей і завдань, і є для особистості як відносно стійкий образ бажаного майбутнього, найважливіший компонент «образу Я» особистості [7].

Ю. Трофімов вказує на те, що з розвитком усіх сфер самосвідомості, формуванням навичок і вмінь роботи над собою, зменшуєть- 
ся розрив між прагненням вдосконалювати себе й реалізацією цього прагнення в діяльності, поведінці та спілкуванні. I тоді самовиховання $з$ епізодичного самозмінення стає постійною властивістю особистості, ii потребою. Позитивні наслідки самозмінення стимулюють до подальшого самовиховання [15].

В психологічній науці виділяються два види самовиховання: вироблення нового в собі i переробка психологічних особливостей, що вже склалися, або фізичних звичок, що припускає їх ломку. Для психологічного аспекту цієї проблеми, І. Чеснокова визначає феномен «самоприобразування», під яким вона має на увазі творчу діяльність особистості, спрямовану на творення самої себе у відповідності зі своїми ідеальними задумами. Найвищого ступеня розвитку самосвідомість особистості досягає тоді, коли людина визначає свої життєві плани і цілі, що обумовлюють життєву стратегію [19].

Висновки. Змістовний аналіз досліджень феноменів самосвідомості дозволив чітKO:

Розрізнити та наповнити конкретним психологічним змістом такі поняття як самопізнання, самовідношення, самооцінка, саморегуляція, самоактуалізація, самореалізація, самоконтроль та самовиховання.

Визначити самооцінку, як особливий феномен самосвідомості особистості, який поєднує в собі результати інтегративної роботи в сфері самопізнання, з одного боку, й у сфері самовідношення - 3 іншого.

Встановити, що головну роль в конструюванні нового стилю життя і трансформації внутрішнього світу особистості сучасна психологія справедливо відводить посиленню процесів пов’язаних з такими феноменами самосвідомості, як самопізнання, самовідношення та саморегуляція.

Визначити саморегуляцію, як циклічний процес постійної актуалізації та реалізації особистістю їі природженого потенціалу.

\section{Перспективи подальших розвідок} полягають у подальших наукових дослідженнях пов'язаних 3 визначенням більш конкретного змісту таких феноменів самосвідомості, як самоактуалізація та самореалізація, а також в практичній діяльності, які мають бути спрямовані на виявленні нових механізмів самосвідомості, що сприятиме більш якісному саморозвитку особистості.

\section{Список використаних джерел:}

1. Білецьький О. М. Дослідження самосвідомості та їі зв'язку із процесами самоактуалізації та самореалізації в психологічній науці / О. М. Білецький // Вісник ХНПУ імені Г. С. Сковороди. Психологія. - Харків: ХНПУ, 2010. - Вип. 33. - С. 38-52.

2. Болотова A. К. Психология развития / А. К. Болотова: [под ред. А. К. Болотовой и О. Н. Молчановой]. М.: ЧеРо, 2005. - 524 c.

3. Деркач A. А. Технологии развития профессионального самосознания личности: [психологоакмеологический практикум] / А. А. Деркач, О. В. Москаленко, В. А. Пятин, Е. А. Селезнева. - Астрахань: Изд -во АГПУ, 2000. - 169 с. 
4. Джеймс У. Введение в философию. Проблемы философии / У. Джеймс, Б. Рассел. - М.: Республика, 2000. $318 \mathrm{c}$.

5. Кольшико А. М. Психология самоотношения: Учеб. пособие / А.М.Колышко. - Гродно: ГрГУ, 2004. - 102 с.

6. Кон И. С. Открытие «Я» / И.С.Кон. - М.: Политиздат, 1978. $-367 \mathrm{c}$

7. Крылов А. Н. «Образ-Я» как фактор развития личности: автореф. дисс. ... канд. психол. наук: 19.00.01 / Крылов Александр Николаевич - Москва, 1984. - 20 с.

8. Леонтьев А. Н. Деятельность. Сознание. Личность / А.Н.Леонтьев. - М.: Смысл, 2005. - 352 с.

9. М'ясоїд П. А. Загальна психологія: Навчальний посібник / П.А.М'ясоїд - К.: Вища школа, 2000. - 479 с. 10. Пантилеев С. Р. Самоотношение как эмоциональнооценочная система: Спецкурс / С.Р.Пантилеев - М.: МГУ, 1991. - 108 с.

11. Поддубная $A$. В. Структура и механизмы становления профессионального самосознания (Психология и жизнь) / А.В.Поддубная. - М.: МОСУ, РПО, 2000. - 357 c.

12. Савчин М. В. Педагогічна психологія / М.В.Савчин. - Дрогобич: «Відродження», 1998. - 200 с.

13. Спиркин А. Г. Сознание и самосознание / А.Г.Спиркин. - М.: Политиздат, 1972. - 471с.

14. Столин В. В. Познание себя и отношение к себе в структуре самосознания личности: автореф. дис. ... докт. психол. наук: 19.00.01 / Столин Владимир Викторович - М., 1985. -37 с.

15. Трофімов Ю. Л. Психологія: Підручник / Ю.Л.Трофімов - К.: Либідь, 2001. - 336 с.

16. Фельдитейн Д. И. Психологические аспекты изучения современного подростка / Д.И.Фельдштейн // Вопросы психологии. - М.: МГУ, 1992. - Вып.№4. - С. 28. 17. Хекхаузен X. Мотивация и деятельность: в 2 т. / Х.Хекхаузен: [пер. с нем.] - М.: Педагогика. - В 2-х.т. 1986. -408 c.

18. Цукерман Г. Сократ и Карлсон [Текст] : [Роль самооценки первоклассника в успешности учения] / Г.Цукерман // Семья и школа. - 1997. - Вып.№12. -
C.10-12.

19. Чеснокова И. И. Проблема самосознания в психологии / И.И.Чеснокова. - М.: Наука, 1977. - 144 с.

20. Шибутани T. Социальная психология / Т.Шибутани: [пер. с англ. В.Б.Ольшанского]. - Ростов н/Д.: Феникс, 1999. - 539 с.

21. Coopersmith S. The Antecedents of Self-Esteem / S.Coopersmith. - San Francisco: Freeman, 1967. - P. 4084.

22. Lecky P. Self-Consistency / P.Lecky- N.Y. :Island Press, 1975. - P. 138-148.

23. Rosenberg M. Society and the Adolescent Self - image / M.Rosenberg. - Princeton University Press, 1965. P.70-74

24. Sagotsky G. Training children's self - control: field experiment in self - monitoring and goal setting in the classroom / G.Sagotsky. - Journal of experimental Psychology, 1978. - P. 242-253.

\section{References (Transliteration):}

1. Biletskiy O. M. Doslidzhennya samosvidomosti ta yiyi zv'yazku iz protsesami samoaktualizatsiyi ta samorealizatsiyi v psihologichniy nautsi / O.M.Biletskiy // Visnik HNPU imeni G.S.Skovorodi. Psihologiya. - Harkiv: HNPU, 2010. - Vip. 33. - S. 38-52.

2. Bolotova A. K. Psihologiya razvitiya / A.K.Bolotova: [pod red. A.K.Bolotovoy i O.N.Molchanovoy]. - M.: CheRo, 2005. - $524 \mathrm{~s}$

3. Derkach A. A. Tehnologii razvitiya professionalnogo samosoznaniya lichnosti: [psihologo-akmeologicheskiy praktikum] / A.A.Derkach, O.V.Moskalenko, V.A.Pyatin, E.A.Selezneva. - Astrahan: Izd-vo AGPU, 2000. - 169 s.

4. Dzheyms U. Vvedenie v filosofiyu. Problemyi filosofii / U.Dzheyms, B. Rassel. - M.: Respublika, 2000. - 318 s.

5. Kolyishko A.M. Psihologiya samootnosheniya: Ucheb. posobie / A.M.Kolyishko. - Grodno: GrGU, 2004. - 102 s.

6. Kon I. S. Otkryitie «Ya»/ I.S.Kon. - M.: Politizdat, 1978. $-367 \mathrm{~s}$.

7. Kryilov A.N. «Obraz-Ya» kak faktor razvitiya lichnosti: 
avtoref. diss. ... kand. psihol. nauk: 19.00.01 / Kryilov Aleksandr Nikolaevich - Moskva, 1984. - 20 s.

8. Leontev A.N. Deyatelnost. Soznanie. Lichnost / A.N.Leontev. - M.: Smyisl, 2005. - 352 s.

9.M'yasoyid P.A. Zagalna psihologiya: Navchalniy posibnik / P.A.M'yasoyid - K.: Vischa shkola, 2000. - 479 s.

10.Pantileev S.R. Samootnoshenie kak emotsionalnootsenochnaya sistema: Spetskurs / S.R.Pantileev - M.: MGU, 1991. - $108 \mathrm{~s}$.

11. Poddubnaya A. V. Struktura i mehanizmyi stanovleniya professionalnogo samosoznaniya (Psihologiya i zhizn) / A.V.Poddubnaya. - M.: MOSU, RPO, 2000. - 357 s.

12. Savchin M. V. Pedagogichna psihologIya / M.V.Savchin. - Drogobich: «Vidrodzhennya», 1998. - 200 s.

13. Spirkin A. G. Soznanie i samosoznanie / A.G.Spirkin. M.: Politizdat, 1972. - 471s.

14. Stolin V. V. Poznanie sebya i otnoshenie $\mathrm{k}$ sebe $\mathrm{v}$ strukture samosoznaniya lichnosti: avtoref. dis. ... dokt. psihol. nauk: 19.00.01 / Stolin Vladimir Viktorovich - M., 1985. $-37 \mathrm{~s}$.

15. Trofimov Y. L. Psihologiya: Pidruchnik / Y.L.Trofimov - K.: Libid, 2001. - $336 \mathrm{~s}$.

16. Feldshteyn D. I. Psihologicheskie aspektyi izucheniya sovremennogo podrostka / D.I.Feldshteyn // Voprosyi psihologii. - M.: MGU, 1992. - Vip.№4. - S. 28.

17. Hekhauzen $H$. Motivatsiya i deyatelnost: v 2 t. / H.Hekhauzen: [per. s nem.] - M.: Pedagogika. - V 2-h.t. 1986. $-408 \mathrm{~s}$.

18. Tsukerman G. Sokrat i Karlson [Tekst] : [Rol samootsenki pervoklassnika $\mathrm{v}$ uspeshnosti ucheniya] / G.Tsukerman // Semya i shkola. - 1997. - Vip.№12. - S.10 --12 .

19. Chesnokova I.I. Problema samosoznaniya v psihologii / I.I.Chesnokova. - M.: Nauka, 1977. - 144 s.

20. Shibutani T. Sotsialnaya psihologiya / T.Shibutani: [per. s angl. V.B.Olshanskogo]. - Rostov n/D.: Feniks, 1999. - $539 \mathrm{~s}$.

21. Coopersmith S. The Antecedents of Self-Esteem /
S.Coopersmith. - San Francisco: Freeman, 1967. - P. 4084.

22. Lecky P. Self-Consistency / P.Lecky - N.Y.: Island Press, 1975. - P. 138-148.

23. Rosenberg M. Society and the Adolescent Self - image / M.Rosenberg. - Princeton University Press, 1965. P.70-74.

24. Sagotsky G. Training children's self - control: field experiment in self - monitoring and goal setting in the classroom / G.Sagotsky. - Journal of experimental Psychology, 1978. - P. 242-253.

\section{Biletskiy Alexey}

Ph.D. in Psychology, director of the development center "The School of Life», Kyiv (Ukraine)

\section{DEFINITION OF THE MAIN PHENOMENONS OF SELF-CONSCIOUSNESS OF THE PERSONALITY}

\section{ABSTRACT}

The article is sanctified to the study of the last researches of the basic phenomena of selfconsciousness, exposing the mechanisms of their realization and hierarchy of influence on development of personality.

In the work it is established that a leading role in constructing of new-style of life and transformation of the inner world of personality modern psychology justly takes to strengthening of processes related to such phenomena of selfconsciousness, as self-knowledge, self-relation and self-regulation.

Life in the collective gradually accustomed people to think about their thoughts and actions before acting and talking, to take into account the possible consequences of the opinions 
expressed and actions taken. Therefore, the appeal to inner peace and inner life of a person is the key moment in understanding man himself. Self-knowledge is this study by personality of own psychical and physical features, comprehension itself. Self-relation is a specific type of the emotional experiencing, in that own attitude of personality is reflected toward that she knows, understands, and opens in relation to itself. It should be noted that the results of integrative work in the field of self-knowledge, on the one hand, and in the sphere of the emotional-value relation to oneself (self-relation), on the other, unite into a special phenomenon of selfconsciousness of the personality - its selfevaluation.

At the same time, the phenomenon of selfregulation should be considered relying on the two-level structure of the I-Concept, where the first level is defined within the framework of the innate human potential, and the second level of the I-Concept is that which forms in a person in the process of socialization and becomes stable in adolescence. This psychological model of the IConcept, as a product of self-consciousness, allows us to define self-regulation as a cyclic process of constant actualization and realization by the personality of its innate potential. Where selfrealization is the process of unfolding the properties and characteristics of a person that are contained at the first level of the I-Concept, into the second level of the I-Concept. And selfrealization is a process of personal development and broadcasting by the personality of her content to other people and culture through the I-Concept of the second level.

The results of recent studies of the main phenomena of self-consciousness point to the need to define more concrete content of such concepts as self-actualization and self-realization, as well as to identify new mechanisms of selfconsciousness that will contribute to a better selfdevelopment of the personality.

Key words: self-consciousness, phenomena of self-consciousness, self-knowledge, selfrelation, self-evaluation, self-regulation, selfcontrol, self-education, self-actualization, selfrealization.

\section{Билецкий Алексей Николаевич}

Кандидат психологических наук, управляющий иентром развития личности «Школа Жизни», г. Киев (Украина)

\section{ОПРЕДЕЛЕНИЕ ГЛАВНЫХ ФЕНОМЕНОВ САМОСОЗНАНИЯ ЛИЧНОСТИ}

Аннотация. Статья посвящена изучению последних исследований основных феноменов самосознания, раскрывающих механизмы их реализации и иерархию влияния на развитие личности.

В работе установлено, что главную роль в конструировании нового стиля жизни и трансформации внутреннего мира личности современная психология справедливо отводит усилению процессов связанных с такими феноменами самосознания, как самопознание, 
самоотношение и саморегуляция.

Жизнь в коллективе постепенно приучила людей обдумывать свои мысли и поступки перед тем, как действовать и говорить, учитывать возможные последствия высказанных мнений и сделанных поступков. Поэтому обращение к внутреннему миру и внутренней жизни человека является ключевым моментом в понимании самого человека. Самопознание - это изучение личностью собственных психических и физических особенностей, осмысление самого себя. Самоотношение - это специфический вид эмоционального переживания, в котором отражается собственное отношение личности к тому, что она узнает, понимает, и открывает относительно самой себя. Следует отметить, что результаты интегративной работы в сфере самопознания, с одной стороны, и в сфере эмоциональноценностного отношения к себе (самоотношения) - с другой, объединяются в особый феномен самосознания личности - ее самооценку.

В то же время, феномен саморегуляции необходимо рассматривать, опираясь на двухуровневое строение Я-концепции, где первый уровень определяется в рамках врожденного потенциала человека, а второй уровень ЯКонцепции - как то, что формируется у человека в процессе социализации и становится устойчивым в подростковом возрасте. Такая психологическая модель Я-Концепции, как продукта самосознания, позволяет определить саморегуляцию, как циклический процесс постоянной актуализации и реализации личностью ее врожденного потенциала. Где самореализация - это процесс развертывания свойств и характеристик человека, которые содержатся на первом уровне Я-Концепции, во второй уровень Я-Концепции. А самореализация, это процесс личного развития и трансляции личностью своего содержания другим людям и культуре через Я-Концепцию второго уровня.

Результаты последних исследований главных феноменов самосознания указывают на необходимость определения более конкретного содержания таких понятий, как самоактуализация и самореализация, а также на выявление новых механизмов самосознания, которые будут способствовать более качественному саморазвитию личности.

Ключевые слова: самосознание, феномены самосознания, самопознание, самооценка, саморегуляция, самоконтроль, самовоспитание, самоактуализация, самореализация.
Дата отримання статті: 01.04.2017 Дата рекомендації до друку: 08.04.2017 